\title{
Reframing the Tower of Babel narrative for economic justice within the South African context
}

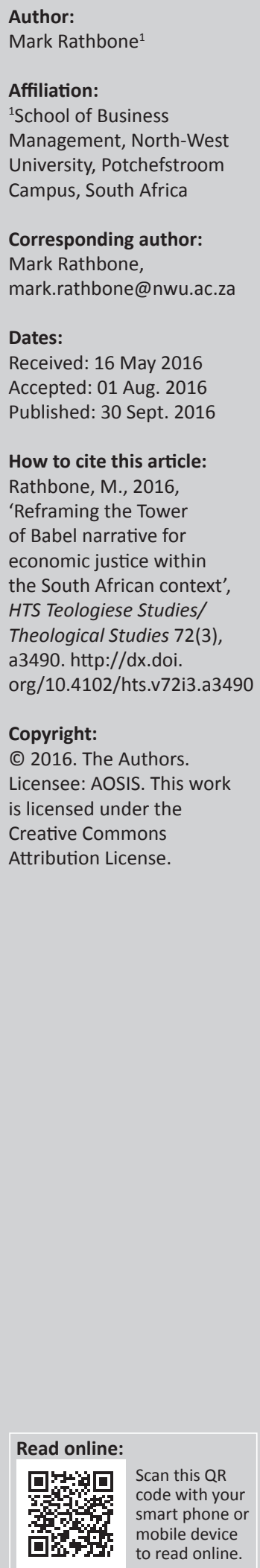

The Tower of Babel narrative is profoundly connected to the history of South Africa and its interpretation in the Dutch Reformed Church document entitled Human Relations and the South African Scene in the Light of Scripture (1976), which was used to justify apartheid. In this article, it is argued that this understanding of the narrative is due to racist framing that morally justified the larger apartheid narrative. The Tower of Babel narrative was later reframed for liberation and reconciliation by Desmond Tutu. However, apartheid had an impact not only on the sociopolitical dynamics of South Africa. Submissions to the Truth and Reconciliation Commission by business and labour highlight the impact of apartheid on the economy and specifically black labour. These revelations are responsible for new questions regarding the economics of the narrative that arise and may enrich the understanding of the Tower of Babel narrative. This focus on the economic aspect of the narrative is also supported by historical research on the Tower of Babel narrative that reveals that the dispersion of the people on the plain of Shinar may refer to the demise of the Sumerian empire, which was among other influences brought about by a labour revolt. In this regard, the narrative is a theological reflection on the demise of an unjust economic system that exploited workers. The purpose of this article is to critically explore this economic justice aspect embedded in the narrative in order to determine whether this reframing of the narrative is plausible. This is particularly important within the post-apartheid context and the increase of economic problems such as unemployment, poverty and economic inequality.

\section{Introduction}

The interpretation of the Tower of Babel narrative ${ }^{1}$ (Gn. 11:1-9) $)^{2}$ in the Dutch Reformed Church document entitled Human Relations and the South African Scene in the Light of Scripture (HR 1976) is a function of racist framing, which highlighted the dispersion of the people on the plain of Shinar and was the moral justification of the apartheid narrative in South Africa. In this paper, narrative is understood as an ontological phenomenon that constructs reality through a continuous process of framing and reframing. Culler (1988:xiv) warns that context may be oversimplified as a given that determines the meaning of acts, because context is not given but produced. Culler (1988:xiv) notes that there is a close connection between event and context because both are determined by interpretative strategies. Culler therefore refers to context as 'framing' in order to highlight that the context is an interpretative event. Framing refers to the 'discursive practices, institutional arrangements, systems of value' that constitute signs (Culler 1988:xiv). In other words, framing is a temporal event referring to place and time. Time and place highlight the ontological nature of framing - they construct reality. The temporality of framing suggests that framing is dynamic and in a continuous process of reinterpretation. This process of reinterpretation highlights what is meant with reframing. Reframing is therefore a function of the temporality of interpretation that has the creative possibility of revealing new aspects of narratives. In other words, the ontology of narrative is not absolute; it is dynamic and enriched by new questions arising because of new circumstances that guide the interpretation process. However, reframing is not a value-neutral process, because framing can be an explicit act of silencing aspects of a narrative to gain control of the story - ontology as power.

The apartheid narrative refers to the collection of narratives that justified, implemented and entrenched apartheid as a system of racial segregation and exploitation. This includes religious texts such as the Tower of Babel narrative; legal texts such as the pass laws and the Group Areas Act; social texts reflected in literature, art and cultural events; and economic texts, among others. These texts contain stories of how race determined the identity and future of the citizens of 1.This article was presented at the 8th Global Conference of The Story Telling Project in Oxford, England, in 2015.

2.The New International Version (2011) is used for all Biblical references. 
South Africa. Many of these texts are interdependent, as is the case with economic narratives that consist of the intersection of law and social narratives. However, narrative as a function of framing is not stable but always in a process of reinterpretation as new circumstances reveals new questions and reframing takes place. This process of reframing the Tower of Babel narrative for liberation is clear in the interpretation of the narrative by Desmond Tutu that responded to apartheid. Both the racist framing of the narrative in HR and the reframing by Tutu highlights that the interpretation of the narrative in South Africa has a clear sociopolitical focus. However, the apartheid narrative also had an impact on the economy of South Africa. This became clear with the Truth and Reconciliation Commission (TRC) and the submission of business and labour. These revelations raise new questions regarding the economics of the Tower of Babel narrative that have previously not been raised. This focus on the economics of the narrative is also supported by historical research on the Tower of Babel narrative that reveals that the dispersion of the people on the plain of Shinar may refer to the demise of the Sumerian empire, which was among other influences brought about by a labour revolt. In this regard, the narrative is a theological reflection on the demise of an unjust economic system that exploited workers. The purpose of this article is to critically explore this economic justice aspect embedded in the narrative in order to determine whether this reframing of the narrative is plausible. This is particularly important within the postapartheid context and with the increase of economic problems such as unemployment, poverty and economic inequality.

In the first section of this article, the Wirkungsgeschichte [history of interpretation] of the Tower of Babel narrative as the dominant racist-framed narrative, as well as reframing for liberation and reconciliation within the South African context, is discussed. Next, the economic impact of apartheid is highlighted by exploring stories of business and labour submitted during the TRC. The final section focuses on historical research that links the narrative to the Sumerian empire and a possible labour revolt that contributed to the dispersion. This theological reflection on the destruction of a possible unjust empire that exploited workers will be critically evaluated to determine whether reframing the Tower of Babel narrative for economic justice is plausible.

\section{The apartheid narrative and the Tower of Babel}

The Tower of Babel narrative had a profound influence on South African society. It is the narrative that formed the basis of the 'apartheid Bible'. The apartheid Bible refers to the racist framing of biblical text in order to theologically justify apartheid; it is part of the larger apartheid narrative (Bax 1983:117; Loubser 1987:ix-x). The Dutch Reformed Church document that theologically justified apartheid, Human Relations and the South African Scene in the Light of Scripture (HR 1976), is a good example of a religious text that was part of the larger apartheid narrative (Rathbone 2015). The story was told from the perspective of Genesis 1:28 where God commands that people fill the Earth. The building of the tower and the gathering of people in one place is therefore viewed as disobedience. The subsequent scattering of the people is an act of punishment and enforcement of God's command. According to HR (1976:16), the scattering of the people that built the city and tower on the plain of Shinar is a direct result of God's judgement for not submitting to his command to replenish the Earth in Genesis 1:28 and Genesis 9:1, 7. God disrupted their language, which resulted in a communication breakdown that brought an end to their unity and the eventual scattering of the people, as was God's wish for humanity, according to HR (1976:16). The confusion of the language of the people and the subsequent scattering is consequently viewed as support of segregation. It is noted in HR (1976:18) that racial diversity is a direct result of the confusion of tongues and the obvious intention of God for society. The conclusion of HR (1976:18) is that racial diversity and segregation is a normative aspect of creation (Rathbone 2015). Thus, the narrative, among others, provided moral justification for segregation policies and laws, literature, art and the economics of the apartheid narrative.

The racist framing of the Tower of Babel narrative can be traced back to the 20-century to as early as 1912 in the sermons of clergy such as J.D. du Toit. His sermon entitled Hemelbestormers views segregation as divine imperative based on the dispersion of the people who inhabited the city on the plain of Shinar. The tower is regarded as a form of forced unification and integration similar to the policies of British imperialism during the early part of the twentieth century. This framing of the narrative was later presented by Du Toit at the 1944 People's Congress in Bloemfontein as the basis for the rejection of 'gelykstelling en verbastering' [equality and inbreeding] imposed by the British and the South African Party (Kinghorn 1986:100-102).

Later, S. du Toit (1969:12-14) follows a similar line of argument as J.D. du Toit. However, he takes it a step further and argues that the Bible is a book of revelations that contains divine imperatives for the structure of society. S. du Toit (1969:54) states that the confusion of tongues is the reason for God's judgement of the people and that it led to the disruption of the building of the tower. The natural language differences (Gn.11:7) among people becomes an unsurpassable division between people that, according to Du Toit, will remain for an eternity. Du Toit is confident that the grace of God is also present in this act. Firstly, God maintains his command that humanity shall fill the Earth; secondly, he prevents humanity from forming a mass union that will result in sin - egoism of power (Gn. 11:6). Therefore, human efforts to create unity will fail because it is against the will of God. The document HR directly follows S. du Toit's argument as a biblical justification for the implementation of apartheid legislation, among others.

The problem is that the racist framing of the narrative is not consistent with Calvin's interpretation. This is important 
because Calvinism is the theological foundation of the philosophy of Kuyper, which influenced many theologians in South Africa and specifically those responsible for HR (Rathbone 2015). Calvin (1948:323-324) notes that the reason for the rebellion of the builders is their pride and disrespect of God. He highlights that the dispersion was a violent intervention by God to subdue the pride of the people, which was located in their display of unity to make a name for themselves. The hubris of the people and not the fact that they did not replenish the Earth was their sin, according to Calvin (Rathbone 2015). Calvin does not relate the event of the building in terms of imperial motives, linked to Nimrod, but he states that it was an encompassing act of rebellion and hubris by society and therefore the disruption affected all the people who lived in this city on the plain of Shinar (Rathbone 2015).

The racist framing not only fails to align with the Calvinist tradition, it is also in conflict with scholarly consensus of the time, which views the dispersion as punishment for hubris, although the work of Van Wolde (2000) is an exception. ${ }^{3}$ Von $\operatorname{Rad}(1963: 147)$ notes that the narrative portrays a primeval situation in which society is disrupted because of their egoism and politics of power, which set them against God as the antagonist. However, their punishment exposed the fragile foundation of their unity and political alliance.

A similar argument is followed by Westermann (1984:557). However, he continues by stating that the focus must turn to the future and the new possibilities made possible by Pentecost. Westermann (1984:557) states that the Pentecost places the sin of the tower builders within '... the context of Acts 2:11 where the good news of the Christ bursts the language barriers ... But it does not in any way alter the plurality and difference of languages'. It is this line of argument that later, in 1983, becomes evident in the reframing of the narrative for reconciliation by Archbishop Emeritus Mpilo Desmond Tutu (1983:39).

Tutu reframes the narrative from the perspective of shalom (peace and unity) by highlighting the order of creation and the unifying role of Pentecost (Rathbone 2014). The narrative is reframed within the context of the unifying role of redemption and Pentecost, which bridges barriers between languages, cultures and races that the sin of hubris corrupts (Tutu 1983:39). Therefore, the narrative is framed as a story of hope that climaxes in the unification of all peoples through the Holy Spirit (Tutu 1983:43). Tutu (1983) contests the biblical justification of apartheid because it:

... contradicts the testimony of the Bible categorically. Whereas the Bible says God's intention for humankind and for His entire

3.One of the problems with these interpretations is that Genesis $1: 28$ mainly focuses on procreation (paw-raw' [fruitfulness] and raw-baw' [multiply]) and control of the Earth or stewardship (kaw-bash' [subdue, tread down, conquer] and raw-daw [control, reign over]). The reference to filling the Earth highlighted by the racist framing of the narrative is therefore made within the context of procreation and framing of the narrative is therefore made within the context of procreation and stewardship over the Earth and not dispersion. It can therefore be argued that this is actually what the people on the plain of Shinar accomplished. Furthermore, the racist framing is in conflict with most influential scholarly interpretations of the text, which focus on the rebellion of the people of Shinar against God. This also align with the context of Genesis 1-11, which focuses on cycles of rebellion and punishment (e.g. Kain and Abel, the flood narrative). This highlights one of the major omissions of the racist framing of the narrative: that it does not pay enough attention to hubris. universe is harmony, peace, justice, wholeness, fellowship, apartheid says that human beings fundamentally are created for separation, disunity and alienation. The apologists of apartheid have sometimes used the story of the Tower of Babel as divine sanction for their ideology of 'separate development' and ethnic identity. (pp. 40-41)

It is clear from the interpretation of the narrative by Tutu that reframing for liberation and reconciliation took place. In this regard, the reframing addresses issues relating to the sociopolitical context of South Africa and the transition to democracy. However, apartheid did not only have an impact on the sociopolitical landscape. Part of the apartheid narrative was the story of economic exploitation and injustice that became apparent during the submission of labour and business to the TRC.

\section{Truth and reconciliation commission, business and workers}

The complex hierarchical relationship between capital, state, managers and workers in the apartheid narrative is highlighted by submissions to the TRC. The report of the TRC was finalised in 1998 and consists of various volumes that contain submissions by individuals, groups and institutions who suffered human rights abuses under apartheid and those who applied for amnesty. The focus in this section is on the submissions of business and labour.

\section{Two narratives of victimhood}

The fourth volume of the TRC report raises questions related to violations of human rights, with special reference to business and labour during apartheid (TRC 1998:18). When studying the submissions of business and labour, it becomes clear that the economic narrative of apartheid consisted of two stories with the same villain - apartheid. The one story is of white business and the other of black business and labour. What follows are the stories of business and labour.

\section{The story of business}

The narratives of mainly corporate businesses such as IBM and the Anglo American Corporation (today Anglo American public limited company) and civil business organisations such as the Afrikaanse Handelsinstituut (AHI) argue that apartheid undermined business activity and economic growth, mainly due to state interference through policies, legislation and developing a culture of separate development and prejudice. ${ }^{4}$ This interference raised the cost of doing business, eroded the skills base and undermined long-term productivity and growth (TRC 1998:19). Apartheid was depicted as the villain and business as one of its many victims because business as a part of society had to submit to the dominant political ideology. Some, such as IBM, admitted that some managers may have ill-treated workers, but that these were isolated incidents (TRC 1998:20). The exception

4.See the submission by Anglo American Corporation regarding the prejudice of the state. The state was accused of interfering and nullifying its bid for Samancor on political grounds (TRC 1998:30). 
was the AHI, which viewed apartheid as the only alternative for justice and peace in South Africa. The AHI stated that, amongst others, white Afrikaans churches, newspapers, cultural organisations and the wider community believed that separate development of the different South African ethnic groups was the best guarantee for justice and peace in the country (TRC 1998:31).

In general, business argued that it did not commit human rights violations and could not be held accountable for state policies. This is highlighted in a statement by Ms Anne Bernstein, who stated that the only responsibility of business is to provide goods and services, jobs and make profit (TRC 1998:41). Therefore, business cannot be held accountable for human rights violations because the constitution, state and elections are there to respond to human rights violations (TRC 1998:41). Business noted, although strained by apartheid policies, it did provide economic benefits for the citizens of South Africa such as jobs and wealth. This reflects the classic neoliberal and capitalist perspective, which makes a clear distinction between business, society and government. However, neoliberalism makes this distinction based on the assumption that the laws of society are just and that all participants have equal opportunity to participate in the economy, which was the case with companies such as Anglo American (Rawls 2005).

Anglo American went a step further and stated that business has a responsibility to improve the lives of people and seek justice. Harry Oppenheimer of Anglo American believed that through industrialisation and economic growth apartheid could be destroyed. He also provided funding for antiapartheid initiatives and resisted oppressive legislation. He sought to provide housing and education. The irony is that the company did not provide enough family accommodation for migrant labourers, ${ }^{5}$ although it was deemed sufficient according to the law. What is clear from this story is that business mostly viewed apartheid as a negative influence on business and its neoliberal values. However, business failed to admit that they benefited unduly at the expense of black business and labour.

\section{The story of black business and labour}

The story of black business and labour was presented by organisations such as the African National Congress (ANC), South Africa Communist Party (SACP), the Black Managers Forum (BMF) and Congress of South African Trade Unions (COSATU). The main thrust of these presentations is that black business and labour were deprived, marginalised and excluded from economic activity. This was mainly because white business benefited from apartheid directly by securing state contracts, influencing legislation and having privileged access to security forces. ${ }^{6}$ The white community and business

5.In an attempt to alleviate the problem of migrant labour the law permitted family accommodation for $3 \%$ of the labour force.

6.The SACP followed a more aggressive criticism of capitalism and apartheid as a form of racial capitalism that used state institutions to subdue black workers by opposing the growth of black trade unions by collaborating with apartheid institutions like the police in order to subdue strikes. (TRC 1998:22). The ANC also highlighted the role police in order to subdue strikes. (TRC 1998:22). The ANC also highlighted the role
that the police played in neutralising union activities (TRC 1998:23). Business influenced government in shaping policies and collaboration. also benefited through job reservation for whites and cheap black labour. ${ }^{7}$ The ANC highlighted that some of the important business organisations and activist groups resisted some of the apartheid laws. However, the majority of business people actively lobbied government to introduce discriminatory laws (TRC 1998:22). An example is the pass laws, which limited black entrepreneurial activity. Later, the Group Areas Act went a step further by preventing black business people from operating in white areas. The Indianowned Avalon Cinemas noted that they were not allowed to operate in white areas, although Ster Kinekor, owned by whites, could do business in Indian areas (TRC 1998:32). Therefore, COSATU stated: 'Apartheid's labour laws, pass laws, forced removals and cheap labour system were all to the advantage of the business community' (TRC 1998:24).

It was also argued that in some cases white business was an antagonist that colluded with the state and directly resulted in human-rights violations. The SACP noted that the perception of the majority of workers was that corporate business collaborated with the apartheid government (TRC 1998:23). The BMF confirmed this by stating:

The human rights violations by business are seen as those policies, practices and conventions which denied black people the full utilisation of their potential, resulting in deprivation, poverty and poor quality of life, and which attacked and threatened to injure their self-respect, dignity and well-being. (TRC 1998:21)

In general, labour presented themselves as the victims of a system of racial capitalism that exploited black workers and destroyed black entrepreneurial activity, leading to economic inequality (TRC 1998:19). The ANC noted that '[a]partheid was associated with a highly unequal distribution of income, wealth and opportunity that largely corresponded to the racial structure of society' (TRC 1998:22).

\section{Business, labour and economic justice}

In the two narratives, apartheid is viewed as the villain and both business and labour perceive themselves as victims. However, the following questions need to be considered. Did white business benefit financially due to apartheid? How did apartheid disadvantage black labour? If business was a victim due to interference by the state and if the state is responsible for socio-economic justice, why did business not do more to resist an unjust state? Consequently, the question is whether it is possible to do business as usual while being aware that all people do not have equal opportunities and access to resources. If business subscribed to neoliberal principles, why was there not a concerted effort to establish fair competition and equal opportunity?

The narrative of victimhood of business unravels once it becomes clear to what extent business benefited from apartheid. The advantage of business was clearly demonstrated in the mining sector, among others, which

7.COSATU states: "We remain of the view that apartheid, with its form of institutionalised racism, masked its real content and substance - the perpetuation of a super-exploitative cheap labour system' (TRC 1998:22). 
benefited most from cheap labour and oppressive policies. The historical background of mining does describe a position of white privilege through strategies that forced black workers into the 'wage system, state-endorsed recruitment practice, capping African wages, divisive labour practices in managing compounds and sometimes brutal repression of workers and trade unions' (TRC 1998:33). In this regard, the Chamber of Mines had a major impact on wages until the mid-1970s (TRC 1998:33). The real wages of Africans in the gold mines were lower in 1970 than in 1915 (34). Other problems were health and safety (TRC 1998:35). In 1986, a polyurethane fire at the Kinross mine, the most devastating catastrophe in the gold mining industry, led to the deaths of 177 workers. The mine only publicised the accident six hours after the event. Later the names and details of only the white miners were released. The black miners were only identified by referring to their ethnicity, without any names or personal details being mentioned (TRC 1998:35-36). Black labour was not only exploited but viewed as inferior with a total disregard for their human dignity, culture and customs. ${ }^{8}$

The above-mentioned are some aspects that highlight the inconsistency in the story of business as a victim of the apartheid narrative. In A History of Inequality, 1652 to 2002 (2002) by Sampie Terreblanche, the economic injustices experienced by black labour in South Africa are traced back to the colonial era. This highlights the disenfranchisement of black labour and the vast amount of wealth accumulated by white business due to colonial exploits and later apartheid. According to Terreblanche (2012:59), the rise of neoliberalism during the Reagan and Thatcher presidencies also had a direct influence on South Africa during the apartheid era, specifically in the mining and energy sectors. This influence continued after democracy through what he calls the 'minerals-energy complex', which colluded with the ANC to continue the impact of neoliberalism in South Africa. The result is that a few elites in government positions and business benefit from capitalism at the expense of workers.

The influence of neoliberalism, as discussed by Terreblanche, does have merit, specifically regarding the abuses that took place and the failure of business to take responsibility for the accumulation of wealth at the expense of black business and labour. Neoliberalism and the power imbalances between white business and black labour cannot be viewed as the sole reason for the current problem of unemployment, poverty and inequality. A more balanced and in-depth analysis is required because neoliberalism encompasses values such as equality and justice (Rawls 2005). It seems that these values were ignored in the pursuit of individual wealth. The neoliberal notion of self-interest was absolutised as a mechanism to exploit black South Africans without taking note of other aspects like equality and justice. This selective use of neoliberal economics was motivated by greed and not neoliberal values ... Neoliberalism is not the villain. It has

8. Business practice also functioned as a means to create feelings of inferiority. Thi was done specifically by rejection of black customs. No leave was given to attend funeral or visit traditional healers, causing anxiety and emotional damage (TRC funeral or visit traditional healers, causing anxiety and emotional damage (TRC
1998:43). Another aspect is that culturally biased psychometric tests were used, 1998:43). Another aspect is that culturally biased psychomet
which caused black people to feel unintelligent (TRC 1998:43). rather been used as a scapegoat. The economic sanction that contributed to the demise of apartheid was ironically rooted in neoliberal values. By limiting international trade, the economy came under pressure and isolated the apartheid government. It was also neoliberal principals that came to the rescue of international markets after the global economic meltdown of the 1980s - low growth rates, dwindling returns on investments, high unemployment and capital flight (TRC 1998:47). In other words, global economic problems such as high interest rates, international recession and the 'Third World' debt crisis were overcome by neoliberalism (TRC 1998:47). This also explains the success of economic sanctions against South Africa that helped to bring about negotiation for change and democracy. The irony is that neoliberalism assisted in bringing about the end of apartheid. If greed and narcissism are responsible for the continued economic problems in South Africa in the name of neoliberalism, it does not mean that neoliberalism and capitalism are the problem. It is greed that is a possible reason for the reluctance of business to take responsibility for economic injustices during apartheid; equal opportunity is a neoliberal principle that was simply disregarded.

This brings us to the second problem of the submission of business and the question of why business did almost nothing (although the endeavours of people such as Oppenheimer are an exception) to resist a clear violation of neoliberal business principles to place the South African economy on a path of growth. If the state unjustly interfered and created a climate of unequal competition and opportunity, why did business not react, instead of supporting and even collaborating with a clearly uneconomic system? Many blame the pervasive nature of the apartheid story. A security police spy stated:

Our weapons, ammunition, uniforms, vehicles, radios and other equipment were developed and provided by industry. Our finances and banking were done by bankers who even gave us covert credit cards for covert operations. Our chaplains prayed for our victory and our universities educated us in war. Our propaganda was carried by the media and our political masters were voted back into power time after time with ever increasing majorities. (TRC 1998:24)

Although the apartheid narrative was pervasive, the drive of business to secure financial benefits from the system went beyond ideology. It seems that the benefit that business received went beyond the ideal of self-interest of economics and the function of the invisible hand to narcissism and hubris (Smith 1950). It is therefore understandable that little or no attempt was made by business to bring about change. It is more a case of religious narratives such as that of Genesis 11:1-9 justifying greed.

\section{Economic injustice and the racist framing of the Tower of Babel narrative}

The clear economic injustice linked to apartheid raises important questions regarding the racist framing of the Tower of Babel narrative. HR framed the narrative with special reference to the dispersion as a divine injunction for 
racial segregation. However, segregation was mainly understood as a sociopolitical and later legal phenomenon. No mention is made of the economics of the narrative and specifically the economic impact of the dispersion. It seems logical to accept that with the dispersion that some were advantaged by settling in locations with resources and fertile agricultural land, while others were not so lucky. Therefore, inherent in the racist framing of the narrative is a clear economic dimension. This question is never raised. However, the TRC raises important questions that may highlight aspects of the text previously neglected and possibly reframed. It is significant that this focus on the economics of the narrative is also supported by historical research on the Tower of Babel narrative, which reveals that the dispersion of the people on the plain of Shinar may refer to the demise of the Sumerian empire, which was among other influences brought about by a labour revolt. In this regard, the narrative is a theological reflection on the demise of an unjust economic system that exploited workers. In the section, this economic aspect is explored and critically discussed as a possible reframing for economic justice.

\section{The Tower of Babel narrative and the economic aspect}

\section{Historical research and the economic aspect}

Historical research highlights important evidence that suggests that the Tower of Babel narrative and dispersion may be linked to historical events surrounding the demise of the Sumerian empire. Van de Mieroop (1999:56) notes that urbanism and monumental structures only materialised in Shinar ${ }^{9}$ after 3500 BC. Furthermore, bricks and bitumen were not used before $3100 \mathrm{BC}-3000 \mathrm{BC}$. Therefore, the historical dating of the tower is not before $3500 \mathrm{BC}-3000 \mathrm{BC}$. However, the dramatic linguistic events described in Genesis 11:1-9 find historical reference to a time between 2100 to 1900 BC in Mesopotamia with the rise and destruction of the Sumerian culture and the Ur III Dynasty (Penley 2007:704). Crawford (1993:18) notes that the Ur III Dynasty was also associated with prosperity and economic activity. The great construction programmes of cities and ziggurats are evidence of this. During this time, cuneiform scripts suggest the prevalence of a Sumerian lingua franca that was disrupted by the invasions of the Amorites and Elamites at about 1960 BC (Dewitt 1979:20).

Research has also shown that possible internal decay preceded the collapse of the empire (Sasson 1995). The internal decay was probably related to the inability of the large and ambitious centralised administration to respond to emergencies such as famine. The labourers were a heterogeneous group consisting of those who worked under compulsion; those who had property and received rations; migrant labourers who travelled among the city-states for employment; and slaves who, due to debt, were sold into slavery (Sallaberger \& Westenholz 1999; Van de Mieroop 2007). Workers were used for these projects but also many Genesis 10:10. other projects related to agriculture (Van de Mieroop 2007). It is possible that revolt could have emanated from the labourers due to their vulnerability during emergencies such as famine. The continued ambition of the centralised administration and an extravagant building project by rulers could have driven the workers to revolt, thereby leading to the overflow of the system as described in the narrative.

\section{Critical evaluation of the possible economic aspect}

In what follows it will be determined whether there is sufficient textual support for the claim of historical research that there is a link between the Tower of Babel narrative and the fall of the Sumerian empire.

\section{Nimrod and imperialism}

Many scholars argue that the narrative is a mythical account that explains the diversity of languages. Early accounts by Driver (1909:132) frame the narrative as an aetiology of linguistic diversity by the Yahwistic author of the narrative. Historical events associated with the Ur III Dynasty make this less plausible. Other scholars frame the narrative as an expression of hubris and the will to power (Tutu 1983:40; Von Rad 1963:147). This focus on hubris as the reason for the dispersion can also be linked to the imperial motive supported by various scholars (Berquist 1996; Brett 2000; Carter 1999; Wenham 1987). This imperialist understanding tells the story of Genesis 11:1-9 from the perspective of Genesis 10:10 and the reference to Nimrod, ${ }^{10}$ associated with imperialism, tyranny and rebellion against God. It also refers to the son of Cush and grandson of Ham, who was cursed, a hunter and socially inept. This framing has direct economic significance and is supportive of historical evidence relating to the Sumerians. Textual and historical evidence makes it plausible that Genesis 11:1-9 may refer to historical events associated with the rise and fall of the Sumerian empire.

\section{Unity, language and technology}

The unifying role of a Sumerian lingua franca noted by historical evidence is supported by the text and the possibility of reference to a Sumerian empire. It is clear from archaeological evidence that the centralisation of power was important to the Ur III Dynasty's building of cities and ziggurats for administrative purposes to manage the empire. Therefore, language and unity may have been the basis for great economic wealth.

A closer reading of the text suggests that language and unity may also be understood in a far wider sense. The unity was reflected in the fact that there was one language of communication (saw-far, sef-eth) and one speech (daw-bawr). ${ }^{11}$ In other words, a unified grammatical structure or language system was in place and the speech or words were unified, making unhindered and effective communication possible.

10. Nimrod is from the Hebrew marad [to rebel]. He is founder of the imperial power in Babylonia and rebelled against God.

11.All phonetic references are taken from Strong's Concordance with Hebrew and Greek Lexicon. 
This reference is extremely important because saw-far and sefeth are not limited to speech. The words saw-far and sef-eth also refer to the margin or lip of a vessel, indicating that it is a boundary, or a particular way of thinking, a frame of reference. It is rather the linguistic system itself that is connected to the frame of reference, the structure of their thought that can be translated into speech, culture and economic system. It is linked to the cognitive process itself (Lakoff \& Johnson 2003). A unified system assists with better communication, as well as faster and seamless trade. The unified administrative system of the Sumerian empire may therefore be implied by the wider understanding of a system of reference. It seems possible that this was the basis for the economic prosperity reflected in the building of a city (eer, awr, aw-yar'mig-dal) and tower (mig-dawl', mig-daw-law') possible on the plain of Shinar.

Nonetheless, the building of the tower was not only a display of wealth, it was also functional. It was built to reach heaven. The connection between heaven and Earth according to the cosmology of the time was re-established by the genius of the people. This cosmic goal is important because it replaces God as the primary actor who initiates cosmic events (e.g. creation, rain, drought, etc.) with the emperor. In other words, people were economically and religiously selfsufficient, although the benefits were only shared by some. God's (yeh-ho-vaw' [self-existent]) action is initiated because of their forced grammatical unity, which led to self-righteous achievements. Their ability to function with a unified system of reference makes the implementation of their plans (zawmam') possible. This is viewed by God as a danger. Some argue it is a danger for God (Derrida 1985). Others argue that it is to protect humanity against self-destruction. It is clear that a unified system is the basis of their $\sin -$ hubris or centralised power, control and pride. God disrupts the system of enforced power and wealth by confounding (baw$\left(a l^{\prime}\right)^{12}$ their linguistic system. Confounding refers to overflow. Disruption was possible by the overflow of the system to reveal its limitations and fragility. In other words, the enforced system could not contain the economic inequality embedded in the system. This overflow resulted in the fragmentation of the system, which has a direct impact on their ability to understand (shaw-mah' [hear]) each other. Therefore, the whole system implodes and the site of human achievement and control becomes the embarrassing display of the ineffectiveness of any system that is taken to its limits. Communication at all levels of society falters and fragments. The building of the city grinds to a halt and the people are scattered all over the Earth. From a deconstructionist perspective the narrative is not merely an expression of the 'irreducible multiplicity of tongues; it exhibits an incompletion, the impossibility of finishing, of totalising, of saturating, of completing something on the order of edification, architectural construction, system and architectonics' (Derrida 1985:165). The one language and/or system are ruptured by the very inclination of systemisation.
In contrast, the building of a city is a testimony of progress and cultural advancement. This is evident from the materials that were used and the method of construction - bricks that were burnt and bitumen as the mortar (v. 3) to strengthen the construction. Not only was the building of the city an engineering achievement, it also signalled the possibility of economic development. A nomadic lifestyle was exchanged for more formal agriculture, crafts and trade. The city was also a place of security with guarded walls (eer [wake, open eyes, guarded fortification]) against any form of danger. The technological advancement, trade and stability achieved by the builders of the city were a function of their unified grammar and speech that may have been influenced by an imperial economic agenda. It also indicates that the people were self-sufficient and innovative. They did not need any external assistance to secure their future. However, they not only built a city, they also built a tower (mig-dawl', mig-daw$\left.l a w^{\prime}\right)$. The semantics of Hebrew indicate that it was a very large, twisting structure that was figuratively viewed as the rostrum of their success - the symbolic pinnacle of prosperity, success and wealth.

This interpretation of the narrative seems acceptable in terms of the reference to the rise and fall of the Sumerian empire and the possibility of internal problems that coincided with the invasion by the Amorites and Elamites. The link between a unified system, Nimrod and a system of reference makes it less likely that Babel was only a symbol of cultural advancement. However, if the association with imperialism and power is more probable, then the question is whether the text supports such a reference to internal strife and revolt of the workers.

\section{Workers}

It is clear from the narrative that the people who lived on the plain of Shinar built the city and tower. However, a building project is not worked on by all the people. There are workers, artisans, project managers, funders, and so on. Furthermore, if Babel refers to a Sumerian empire, it is logical to presume that those in power did not participate in the building of the city and tower. They may have given the instruction and possibly funding to do the actual building. In this case, they may have used various types of labour, as is clear from historical reference. Some may have been slaves, other contract workers, craftsmen, and so on.

What is of interest is that the people are identified as a collective unit - the people who journeyed, who had one language and speech, who settled in the land of Shinar and who built the city and tower. This collective is misleading because it creates the impression that all people did all the work. However, from accounts from the ancient Near East, there must have been a monarchy or something similar, those in power who associated with the monarchy, military forces, artisans, farmers, peasant peoples and slaves. In all probability, the people who built the city and tower were the slaves, peasantry and artisans, who collectively were the workers and actual builders of the city and tower. They were 
probably also the people who benefited the least and had the least say as to the extensive building projects. The unity of language and speech simply creates the impression that there was no tension in this idyllic community.

The fact that Babel and Shinar are associated with the empire of Nimrod suggests that there was a possible hierarchy with great tension in this society. This possibility sheds more light on the possible impact of the overflow that resulted in the dispersion. The one frame of reference is functional for communication and the success of building project; however, it does not mean that there were no other pressures on the system. The pressure escalated due to the possible exploitation of the workers perpetuated by the greed of those in power, leading to the dissatisfaction of the workers, their revolt and the eventual implosion of the system. The consequence is that the complex and hierarchical relations and tension between the people of Shinar came into consideration. However, the possibility that this tension resulted in the implosion of the unified system of reference implemented by the empire is not clear from the text. The suggestion that the invasion of the Amorites and Elamites coincided with a workers' revolt may therefore be problematic. It is clear from Genesis 11:1-9 that workers were used to build the city and tower. This remarkable achievement was made possible by one language that made communication possible. At no point in the narrative is it stated that the workers were unhappy or exploited. Although historical evidence suggests that this may have been the case during the fall of the Ur III Dynasty, it is not evident from the narrative.

\section{Economic reframing of the Tower of Babel narrative}

The clear evidence during the TRC that apartheid benefited white business makes this an important aspect to consider within the South African context. It contributes to new questions that may bring new aspects of the Tower of Babel narrative to the surface, because the racist framing does not incorporate the economics of the narrative. Furthermore, historical evidence of a labour revolt makes it appealing to reframe the narrative for economic justice. In this regard, the dispersion may be viewed as a form of implosion of a greedy and tyrannical empire. It also highlights that the divine rejects economic exploitation and inequality.

However, the reframing runs into many problems, as mentioned in the previous section. The main problem is that there is no reference to internal strife before the dispersion took place. This should caution anyone attempting to reframe the narrative for economic justice. That said, there are important aspects that concur with contemporary research that do support the role of economics and justice. This is the reference to Babel and Nimrod and the possible Sumerian link. In this regard, the narrative can be economically reframed. The building of the tower is a clear display of power made possible by the unified empire. It underscores the fact that there is a large amount of wealth and prosperity. However, the hubris may not be connected to all the builders but may rather be associated with the arrogance and narcissism of the empire (Berquist 1996; Von Rad 1963; Westermann 1984). The disruption of the system does logically make sense as a punishment of the empire, thereby setting the people free. The justice aspect is linked to the silenced workers.

\section{Conclusion}

In this article the role of the Tower of Babel narrative was discussed within the South African context as a function of framing and reframing. In this regard, the narrative was used to legitimise apartheid by means of racist framing. The dispersion of the people on the plain of Shinar was viewed as a divine imperative supporting racial segregation. It later became evident during the TRC submission of business and labour that apartheid privileged white business at the expense of black labour. The racist framing of Genesis 11:1-9 made no mention of the economics of the narrative. In this regard, the TRC reveals new questions for the interpretation of Genesis 11:1-9 and the possible reframing of the narrative. The move to reframing has become more probable with reference to historical research that links the Tower of Babel narrative to the Sumerian empire and a worker revolt. This probable reframing was investigated in terms of textual references and it was found that the notion of empire, power and wealth does have evidence in the text. However, the probability that Genesis 11:1-9 is a worker revolt is remote and not very plausible. Reframing for economic justice may have merits in terms of the hubris of empire and the inequality between labour and monarchy. This is also supported by a wealth of scholarly research.

\section{Acknowledgements Competing interests}

The author declares that he has no financial or personal relationships that may have inappropriately influenced him in writing this article.

\section{References}

Bax, D., 1983, 'The Bible and apartheid 2', in J.W de Gruchy \& C. Villa-Vicencio (eds.), Apartheid is a heresy, pp. 112-143, David Philip, Cape Town.

Berquist, J.L., 1996, 'Postcolonialism and imperial motives for canonization', Semeia 75, 15-35.

Brett, M.G., 2000, Genesis: Procreation and the politics of identity, Routledge, London.

Calvin, J., 1948, Commentaries on the First Book of Moses called Genesis, Translated Rev John King, WM. B. Eerdmans Publishing Company, Grand Rapids, Michigan.

Carter, C.E., 1999, The emergence of Yehud in the Persian period: A social and demographic study, Sheffield Academic Press, Sheffield.

Crawford, H., 1993, Sumer and the Sumerians, Cambridge University Press, New York. Culler, J., 1988, Framing the sign: Criticism and its institutions, Norman, London.

Derrida, J., 1985, 'Des Tours de Babel', in J.F. Graham (ed.), Difference in translation, transl. J.F. Graham, Cornell University Press, London.

Dewitt, D.S., 1979, 'The historical background of Genesis 9:1-11: Babel or Ur?', Journal of the Evangelical Theological Society 22, 15-26.

Driver, S.R., 1909, The book of Genesis: With introduction and notes, Methuen \& Co, London.

Du Toit, J.D., 1912, Hemelbestormers, Het Kerkbode, 15 November, 38-42.

Du Toit, S., 1969, Openbaringsgeskiedenis van die Ou Testament, Pro Rege-Pers Beperk, Potchefstroom.

HR, 1976, Human relations and the South African scene in the light of scripture, National Book Printers Ltd, Cape Town. 
Kinghorn, J., 1986, Vormende Faktore, in Die NG Kerk en apartheid, pp. 47-69, SigmaPers Bpk, Pretoria.

Lakoff, G. \& Johnson, M., 2003, Metaphors we live by, University of Chicago Press, London

La Sor, W.S., Hubbard, D.A. \& Bush, F.W., 1991, Old Testament survey: The message, form and background, William B Eerdmans Publishing Co, Grand Rapids, MI.

Loubser, J.A., 1987, The apartheid Bible: A critical review of racial theology in South Africa, Maskew Miller Longman, Cape Town.

Penley, P.T., 2007, 'A historical reading of Genesis 11:1-9: The Sumerian demise and dispersion under the UR III dynasty', Journal of the Evangelical theological Society 50(4), 693-714.

Rathbone, M., 2014, 'The Tower of Babel Narrative in the African context', Acta Theologica 34(1), 173-196. http://dx.doi.org/10.4314/actat.v34i1.10

Rathbone, M., 2015, 'Sphere sovereignty and irreducibility: The ambiguous use of Abraham Kuyper's ideas during the time of apartheid in South Africa', Koers 2015(1), 1-8. http://dx.doi.org/10.19108/koers.80.1.2208 Rawls, J., 2005, Political liberalism: Expanded edition, Columbia University Press, New

Sallaberger, W. \& Westenholz, A., 1999, Mesopotamie: Akkade-Zeit und Ur III-Zeit, Vanderhoeck \& Ruprecht, Gottingen.

Sasson, J.M., 1995, Civilizations of the ancient Near East, Scribner, MI.

Smith, A., 1950, An inquiry into the nature and causes of the wealth of nations, edited with introduction, notes, marginal summary and an enlarged index, Cannan, E., London.
Terreblanche, S., 2002, A history of inequality, 1652-2002, University of Natal Press, Pietermaritzburg.

Terreblanche, S., 2012, Lost in transformation: South Africa's search for a new future since 1986, KMM Review Publishing Company, Johannesburg.

Truth and Reconciliation Commission of South Africa Report, vol. 4, 1998 , viewed 10 March 2015, from http://www.justice.gov.za/trc/report/finalreport/ Volume\%204.pdf

Tutu, D., 1983, 'Christianity and apartheid', in J.W de Gruchy \& C. Villa-Vicencio (eds.), Apartheid is a heresy, pp. 39-47, David Philip, Cape Town.

Van De Mieroop, M., 1999, The ancient Mesopotamian city, Oxford University Press, Oxford.

Van De Mieroop, M., 2007, A history of the ancient Near East, ca 3000-323 BC, Blackwell, Malden, MA.

Van Wolde, E., 2000, 'The earth story as presented by the Tower of Babel narrative', in N.C. Habel \& S. Wurst (ed.), The earth story in Genesis, pp. 147-157, Sheffield Academic Press, England.

Von Rad, G., 1963, Genesis: A commentary, SCM Press Ltd, London.

Wenham, G.J., 1987, Word Biblical commentary Vol. 1, Genesis 1-5, Word Book, Waco, TX.

Westermann, C. 1984, Genesis 1-11: A commentary, Augsburg Publishing House, Minneapolis, MN. 